\title{
Cattle Marketing in Mubi Area of Adamawa State, Nigeria
}

\author{
A. A. Mubi ${ }^{1}$., S. A. Michika ${ }^{2}$ and A. Midau ${ }^{1}$ \\ ${ }^{1}$ Department of Animal Production, Adamawa State University, Mubi, Nigeria \\ ${ }^{2}$ Ministry for Livestock and Nomadic Settlement, Adamawa State, Nigeria
}

\begin{abstract}
This study is basically concerned with the marketing of cattle in Mubi Area of Adamawa State. It examined the strategies and procedures of marketing cattle and it investigates the socioeconomic characteristics of cattle marketers. The methods and techniques includes; collection of relevant data through the use of questionnaires, where a total of one hundred questionnaires were randomly distributed to various cattle marketers in the study area, their responses used for the analysis and interpretation of the result. The use of tables, frequencies and percentages were employed. The result showed $66 \%$ of the respondents were married. Poor educational status of the marketers (4-27\%) also affects cattle marketing negatively. The result also shows that $5 \%$ of the marketers transport their animals on hooves and vehicles. The result of factors considered in buying also indicates more marketers at $75 \%$ consider size. Retailers, comprises $43 \%$ of the marketers. Age of the marketers, marital status has no negative effect on the marketing of cattle in this study.
\end{abstract}

\section{INTRODUCTION}

Marketing of cattle in Mubi South Local Government Area of Adamawa state, is an economic activity common to all the districts within the Local Government Area. There are days designated for cattle marketing. Many people who participate in the marketing activities depend on it as their sources of income, as cited by Agboola, S.A. (1979).

Marketing of cattle, just like in all other Local Governments in Adamawa state is an activity carried out in order to satisfy the economic needs and wants of the people. From this point of view, cattle marketing can be said to be the performance of all business activities which directs the smooth flow of cattle to consumers from sellers in order to accomplish the producer's objective.

Cattle marketing have played a vital role in Nigeria. The importance includes; economic, social and cultural contributions to the people involved in rearing and marketing of cattle, (Consortium, 1969). The Local Government, the State and the Federal Government also benefit from the revenue generated from the cattle markets.

Marketing of cattle in the Local Government is a function of so many factors among which are, transportation, pricing and financing, risk bearing and keeping of cattle for future marketing.
The improved transportation system has helped to increase the scope of the marketing operation. The numerous feeder roads in Mubi South Local Government Area ensure that weekly markets enjoy the patronage of the Fulani from satellite camps.

Sixty percent of the marketable cattle crossing National boarders are destined to Nigeria (Von Kaufmann, 1986); Mubi South Local Government Area is one of the leading livestock markets in the state. More than half of the cattle traded are from neighbouring Chad, Niger and Cameroon. By building more roads, abattoirs, slaughter slabs, and cattle market, the Local Government has boosted livestock trading in the area. These facilities also help in creating a demand and supply culture for merchantable goods and services in the area as reported by (Ismail, 2008).

The domestic cattle found in Africa, south of sahara must have probably originated from Nubia, moved south wards towards the Nile valley. Wrigley, (1960) and Agboola, (1979). Once the desert barrier is crossed, the cattle could have spread to other parts of the continent including Nigeria.

Agboola, (1979) asserted that the Zebu breed which is among the cattle sold in some parts of the country, must have originated from the above sources. The Fulani men are known to be the major livestock owners. 
Cattle are large ruminant animals domesticated and sold for their products such as milk, meat, hides, cheese etc.

Owing to the low level of animal protein consumption in Nigeria, at present and expected demand in the future, cattle are considered to provide nutritionally superior foods and the output has to be substantially increased in order to ensure adequate supply of protein to the growing population, (Consortium, 1969). Net amount of livestock products has been estimated about 1.1 million tonnes Agboola, (1979). Out of the 1.1 million tones, the beef cattle for which most of productions of Nigerian cattle are based accounted for the larger percentage.

Cattle play a very important role in Nigeria agriculture, Nigeria is one of the four leading cattle producers in sub-sahara. In 1990, the cattle population was estimated to be about 14 million, however these figures have since increased to 15.2 million (FAO, 2006). However, data on meat and milk production, live animals and milk product imports, it is noted that, while beef and veal, goat and game meat production have gradually increased over this period, the production of sheep meat has doubled from 1995 to 2004. Large numbers of cattle, sheep and goats are imported as well as various milk products to a value of about two hundred and fifty million dollars in 2003 (FAO, 2006).

As a result of this, there is need to tackle the problem of increase in demand for cattle products which will led to increase in productivity and subsequently efficiency in marketing of cattle in Mubi South Local Government Area just like other parts of the country.

Cattle vary from other livestock on account of varying size outside households. They are almost completely dependent on open pastures and transhumance especially during rainy season. However, in Mubi South Local Government Area, the close association of Fulani herdsmen with the breeding and rearing of cattle has given this aspect of livestock economy some distinct socio-economic relevance which deserves separate attention.

Cattle marketing play an important role in the development of the nation. In spite of this importance, the problem of poor marketing system of cattle in the study area is alarming. The problems encountered can be clearly seen right from the place of production to the final destination. Problems of stress during transit, sources of supply, incidence of disease of economic importance, speculative activities of middle men, lack of general information or knowledge about the sources of supply and demand for the cattle and revenue generation are encountered among others.

Despite the high demand for cattle and its products, the supply is hampered by certain variables such as poor transportation, high cost of animal which invariably affect revenue generation for the Local Government and the State as well, which actually has necessitated this study.

This study is aimed at finding solutions to problems of cattle marketing and revenue generation in Mubi South Local Government Area of Adamawa State, it will serve as a guide to extension workers, researchers, and students and further evaluation of the study of cattle marketing and revenue generation in Mubi South Local Government Area of Adamawa State and the nation at large, it can also be used by the government for policy formulation on cattle production, marketing and revenue generation. This study was conducted to investigate the socioeconomic characteristics of cattle marketers, to identify the general problems of cattle marketing with the view to proffering solutions, to determine the strategies and procedures for marketing cattle in order to maximize profit and to the source of funds involved in cattle marketing.

\section{Research Methodology}

Study Area: Mubi Area of Adamawa State is located on Latitude $11^{\circ} 5^{\prime} \mathrm{N}$ and Longitude $13^{0} 5^{\prime} \mathrm{E}$. It has altitude of 696 meters above sea level with an annual mean rainfall of $1,220 \mathrm{~mm}$ and a mean temperature of $15.2^{\circ} \mathrm{C}$ during Hamattan periods from November to February and $39.7^{\circ} \mathrm{C}$ in April (ADADP, 1986). The town is essentially a mountainous landscape transverse by river Yedzaram and many tributaries, Mandara and Adamawa Mountains formed part of this undulating Landscape (Mansir, 2006).

The Area contains Gude, Fali, Fulani and other tribes dominated the area with a lot of pasture land. As such it formed an important breeding ground for cattle and hence the formation of one of the largest cattle market in the state, Mubi International Cattle Market which is situated in Mubi South Local Government Area. The market as such, formed an area of contacts with cattle marketers.

Economic resources in the Local Government Area centers on Agriculture, cash crops like groundnuts and beans are grown while food crops like rice, maize, and sorghum are grown equally.

Along the river Yedzaram and many of its tributaries, a lot of vegetables gardening in dry season are 
practiced. Fishing is also undertaken in the revering areas. The major occupation of the people in the Area is farming and marketing.

Cattle Breeds Found In the Study Area: The predominant breeds of cattle in Adamawa State are; Adamawa gudali, Sokoto gudali, White Fulani are the cattle commonly marketed in the study area, even though, others like Red Sokoto and Red Fulani are also marketed in these area, (Frick, 1983).

Sources of Data and Sampling Procedure: A market survey was conducted at Mubi International Cattle market at various cattle market days in the study area. One hundred questionnaires were distributed and administered at random to various marketers of Cattle and their responses were used in making analysis of the findings.

\section{Statistical Analysis}

The analytical technique adopted in this study was frequency and percentages. Data collected was subjected to simple descriptive statistics.

\section{RESULTS AND DISCUSSION}

Socio- Economic Characteristics: The social factors considered include the following: Sex, Marital status, Educational level, Marketing experience and Source of cattle supply among others

Sex Distribution of Respondents: The study revealed that all the respondents were men (100\%). This was attributed to the marketing tasks involved; this coupled with the fact that the Northern Muslims which formed the largest population of the marketers do not allow their wives to go out for such business as reported by Fenn (1977) and Auwal (2005).

Table 4.1.1: Sex Distribution of Respondents

\begin{tabular}{|l|c|c|}
\hline Sex & Frequency & $\begin{array}{c}\text { Percentage } \\
(\%)\end{array}$ \\
\hline Male & 100 & 100 \\
\hline Female & 0 & 0 \\
\hline TOTAL & $\mathbf{1 0 0}$ & $\mathbf{1 0 0}$ \\
\hline
\end{tabular}

\section{Age Distribution of Respondents}

Table 4.1 .2 below presents the data based on the age group of the cattle marketers, from the table; it can be observed that the sample participants have different age group. Out of the 100 respondents, 35\% are between the age of less than 30 years, 33\% of the respondents are between the age group of $31-$ 40 years and $32 \%$ are in the age of 41 years and above. This implies that both the youth and the aged can successfully make marketing a business to live on, but the younger ones are more active than the aged and invariably more into the business. (FAO, 1990).

Table 4.1.2: Age Distribution of Respondents

\begin{tabular}{|l|c|c|}
\hline Age & Frequency & $\begin{array}{c}\text { Percentage } \\
\text { (\%) }\end{array}$ \\
\hline $\begin{array}{l}\text { Less than 30 } \\
\text { years }\end{array}$ & 35 & 35 \\
\hline $31-40$ & 33 & 33 \\
\hline 41 and above & 32 & 32 \\
\hline TOTAL & $\mathbf{1 0 0}$ & $\mathbf{1 0 0}$ \\
\hline
\end{tabular}

\section{Marital Status of Respondents}

Table 4.1.3 presents the marital status of the respondents in the Local Government Area. 27\% were single, and $66 \%$ were married while the remaining 7\% were divorced. A similar result was obtained by Kohls and Uhls, 1985. This implies that marketing of cattle is a profitable venture, sustain individual and families.

Table 4.1.3: Marital Status of Respondents

\begin{tabular}{|l|c|c|}
\hline Marital status & Frequency & $\begin{array}{c}\text { Percentage } \\
(\%)\end{array}$ \\
\hline Single & 27 & 27 \\
\hline Married & 66 & 66 \\
\hline Divorced & 7 & 7 \\
\hline TOTAL & $\mathbf{1 0 0}$ & $\mathbf{1 0 0}$ \\
\hline
\end{tabular}

\section{Educational level of Respondents}

Table 4.1.4 presents the educational level of respondents. The result indicate; $9 \%$ of the respondents have primary education, $27 \%$ attended secondary education , $10 \%$ attended tertiary education, $11 \%$ both Qur'anic and primary education and 4\% attended both Qur'anic and secondary education, in contrast with (Wakili,1996) who recorded least number of respondents with Qur'anic education and more attended post primary, with $18 \%$ and $32 \%$ respectively. 
From the analysis, it indicates that most of the marketers lack formal education which attributed to lack of improper keeping of records, lack of communication during marketing among others, this could affect efficient marketing activities, Schultz ( 1995 ), requires that education enhance persons ability to deal with economic disequilibria.

Table 4.1.4: Educational level of Respondents

\begin{tabular}{|l|c|c|}
\hline Educational level & Frequency & $\begin{array}{c}\text { Percentage } \\
(\%)\end{array}$ \\
\hline Primary & 9 & 9 \\
\hline Secondary & 27 & 27 \\
\hline Tertiary and & 10 & 10 \\
\hline Qur'nic and Primary & 11 & 11 \\
\hline $\begin{array}{l}\text { Qur'nic } \\
\text { Secondary }\end{array}$ & $\mathbf{1 0 0}$ & 4 \\
\hline TOTAL & $\mathbf{1 0 0}$ \\
\hline
\end{tabular}

\section{Marketing Experience of Respondents}

As shown in table 4.1.5. below, $73 \%$ of the cattle marketers have cattle marketing experience ranging from $1-10$ years, $19 \%$ of the respondents have 11 20 years experience , $6 \%$ have 21 - 30 years experience and $2 \% 31-40$ years experience. This shows that many respondents have been in the business for along time and many are coming in, it is only those that stayed very long in the businesses that are few. This can be attributed to their ages. The data reveals that Mubi South Cattle market is fast expanding and more people keep coming into the business.

Table 4.1.5: Distribution of marketing Experience of Respondents

\begin{tabular}{|l|c|c|}
\hline $\begin{array}{l}\text { Experience level in } \\
\text { years }\end{array}$ & Frequency & $\begin{array}{c}\text { Percentage } \\
\text { (\%) }\end{array}$ \\
\hline $1-10$ & 73 & 73 \\
\hline $11-20$ & 19 & 19 \\
\hline $21-30$ & 6 & 6 \\
\hline $31-40$ & 2 & 2 \\
\hline TOTAL & $\mathbf{1 0 0}$ & $\mathbf{1 0 0}$ \\
\hline
\end{tabular}

\subsubsection{Marketing Agencies}

The retailer agents formed 43\%, while the commission agents and wholesaler formed $21 \%$ and $36 \%$ respectively. Ajiya (1998) reveal insufficient capital by other commission agents is as a result of not being in the business for along time, therefore they are not well established.

Table 4.1.6: Distribution of Marketing Agency

\begin{tabular}{|l|c|c|}
\hline Agent & Frequency & $\begin{array}{c}\text { Percentage } \\
(\%)\end{array}$ \\
\hline Retailer & 43 & 43 \\
\hline $\begin{array}{l}\text { Commission } \\
\text { Agent }\end{array}$ & 21 & 21 \\
\hline Wholesaler & 36 & 36 \\
\hline TOTAL & $\mathbf{1 0 0}$ & $\mathbf{1 0 0}$ \\
\hline
\end{tabular}

\section{Transportation of Cattle}

The transportation of cattle to market is usually on hooves or by vehicle for a distance market, it depends on the circumstances, sometimes it can be both on hooves and vehicles. In Mubi South, 67\% of the respondents transport their cattle by vehicles, $28 \%$ transport them on hooves, while $5 \%$ on both hooves and vehicles. Fenn (1977), who indicates marketing, involved a variety of transportation methods by road, rail, ship and air. It also depends to a large extend on a network of reliable roads that links the producer to the markets and the main towns. Also Akinwumi (1986) observed that the distance covered, type of vehicle, the number of animal carried, all affect transportation cost.

Table 4.1.7: Distribution of mode of Transportation of Cattle

\begin{tabular}{|l|c|c|}
\hline $\begin{array}{l}\text { Mode of } \\
\text { transportation }\end{array}$ & Frequency & $\begin{array}{c}\text { Percentage } \\
\text { (\%) }\end{array}$ \\
\hline By Vehicles & 67 & 67 \\
\hline On Hooves & 28 & 28 \\
\hline Hooves and Vehicles & 5 & 5 \\
\hline TOTAL & $\mathbf{1 0 0}$ & $\mathbf{1 0 0}$ \\
\hline
\end{tabular}

\section{Factors Considered in Buying Cattle}

Table 4.1.8 shows the factors considered in buying cattle, $75 \%$ of the marketers consider the cattle size before purchase, $17 \%$ consider sex, while $8 \%$ consider colour. This was due to the ever increasing demand of the beef which most of the consumers give preference to other factors such as sex, colour, 
age and others, are considered only by farmers who are trying to replace the animals they culled.

Table 4.1.8: Distribution of Factors Considered in Buying Cattle

\begin{tabular}{|l|c|c|}
\hline Factors & Frequency & $\begin{array}{c}\text { Percentage } \\
(\%)\end{array}$ \\
\hline Size & 75 & 75 \\
\hline Sex & 17 & 17 \\
\hline Colour & 8 & 8 \\
\hline Others & 0 & 0 \\
\hline TOTAL & $\mathbf{1 0 0}$ & $\mathbf{1 0 0}$ \\
\hline
\end{tabular}

Sources of Capital for Cattle Marketing: Table 4.1.9 below shows that, $40 \%$ of the marketers obtained their capital from relatives and friends, $28 \%$ from Banks, $27 \%$ from fellow traders, while $5 \%$ from other sources. The sources of capital to start the business of cattle marketing is another important issue to be considered, this is because, how much an individual marketers have and what source of his capital, determines the state of their business.

Table 4.1.9: Distribution of Source of Money for Cattle Marketing

\begin{tabular}{|l|l|l|}
\hline Source & Frequency & $\begin{array}{l}\text { Percentage } \\
(\%)\end{array}$ \\
\hline Relatives/Friends & 40 & 40 \\
\hline Loans from Banks & 28 & 28 \\
\hline Other Marketers & 27 & 27 \\
\hline Others & 5 & 5 \\
\hline TOTAL & $\mathbf{1 0 0}$ & $\mathbf{1 0 0}$ \\
\hline
\end{tabular}

\section{Conclusion and Recommendation}

Conclusion: Based on the findings in this study, marketing of cattle in the study area can be said to be profitable venture if special consideration is given to tackle the problem militating against smooth and efficient marketing. Such problem traced when addressed properly, the strategies, procedures in cattle marketing will be improved.

Recommendation: Based on the result obtained, the following recommendations are looked into, in order to improve the cattle marketing in Mubi South Local Government Area of Adamawa State. Government should intensify efforts to encourage the production of cattle. This can be achieved by providing incentives to producers in terms of loan or credit through Banks. To overcome the problem of theft, the marketers should form strong organization to see that any strange or suspected person that brought cattle to the market is strictly scrutinized before selling.

Local Government should assist in the formation of a body charged with the responsibilities of passing information to producers and marketers on the supply, demand and price of cattle in the market. Government should encourage the herdsmen to settle in one area by establishing a range land or pasture development. There is need for the provision of modern cattle marketing facilities like standard weighing scale, loading space, and grades in the markets; this will help in transforming the market from the current traditional system.

Government should provide more veterinary facilities to minimize incidence of diseases and parasites. Cattle should be properly checked before buying and selling. Quarantine stations be located in strategic places to avoid diseased animals into the market.

\section{REFERENCE}

ADADP. (1986). Adamawa Agricultural Development Programme. Method of Vegetable Gardening. Page 3-4.

Adebayo, A.A. (1999). Climate, Sunshine, Temperature, Relative humidity and Rainfall. Journal of Applied Sciences and Management. Vol.1. Page 69 -72.

Agboola, S.A. (1979). An Agricultural Atlas of Nigeria. First Edition, Oxford University Press Limited, London, page-26, 153-156.

Ajiya, K. (1998). Student Final Year Project. Department of Agricultural Economics and Extension. Federal University of Technology Yola. Unpublished.

Akinwumi, J.A. (1986). The Nigerian Livestock Industry (Problems and Prospects). A Journal on the proceeding of workshop on the proposed SubLivestock sector review held in Jos, $26^{\text {th }}-27^{\text {th }}$ February.

Auwal, A. (2005). Political Decisions in Nigerian Agricultural Industry. Journal of Applied Sciences and Management, Vol.2. Page 186.

Consortium for the Study of Nigerian Rural Development (1969). Published by National Institute for Policy and Strategic Studies, Kuru, Jos. Page 3-10. 
FAO. (1990). Production Year Book. Volume 46, page 153 Rome, Italy.

FAO. (2006). Trypanotolerant Cattle and Livestock Development in West and Central Africa. Animal Production Health Paper, 67/1 vol.II. Page 213230.

Fenn, M.G. (1977). Marketing Livestock and Meat, FAO. Animal Production and Health Series No.1. $2^{\text {nd }}$ Edition. FAO: Rome, Italy.

Frick, C. (1983). The Open Niche, Pastoralism and Sedentarization in the Mambila Grassland of Nigeria. Page 13-15.

Ismail, I. (2008). Livestock Transportation and Marketing in Nigeria. expro@erols.com

Kohls, R.L. and Uhl, J.N. (1985). Marketing of Agricultural Products. Sixth Edition, McMillan Publishers Company, New York. Page 5 - 8.
Mansir, M. (2006). Livestock Marketing and Transportation in Nigeria. expro@erols.com

Schutz, P. (1995). Agricultural Economics For Tropical Africa, London: Heinemann. Page 86.

Von Kaufmann, R. (1986). The Establishment and Management of Fodder Banks. "In Livestock Systems Research in Nigeria's Sub humid Zone "Proceedings of a second I.L.C.A. IN.A.P.R.I. Symposium held in Kaduna, Nigeria. Page 326.

Wakili, B.A. (1986). Connection and Profit Margin of Cattle marketing in Maiduguri. Student Final Year Project. Department of Agricultural Economics and Extension. University of Maiduguri, unpublished.

Wrigley, J. (1960). "Livestock, Merchant Capital and Under Development in Nigeria". Presented at a Panel on "Trade Organisations and Local Development in West Africa", African Studies Association Annual Meeting (Washington, D.C.). Page 102. 